ENTREPRENEURSHIP AND SUSTAINABILITY ISSUES

ISSN 2345-0282 (online) http://jssidoi.org/jesi/

2019 Volume 6 Number 3 (March)

http://doi.org/10.9770/jesi.2019.6.3(18)

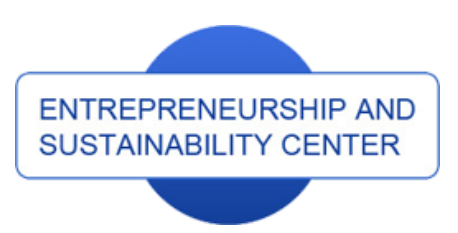

Publisher

http://jssidoi.org/esc/home

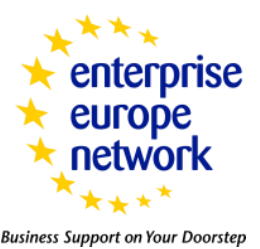

CASPA

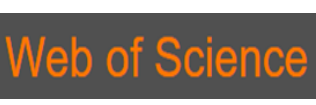

Clarivate
Analytics

\title{
PREREQUISITES FOR THE DEVELOPMENT AND PROSPECTS OF ORGANIC AGRICULTURAL PRODUCTS MARKET
}

\author{
Alina Proshchalykina ${ }^{1}$, Yevhenii Kyryliuk ${ }^{2}$, Iryna Kyryliuk ${ }^{3}$ \\ 1,2,3 Bohdan Khmelnytsky National University of Cherkasy, 81 Shevchenko Boulevard, Cherkasy, Ukraine \\ E-mails: ${ }^{1}$ alina1026@ukr.net $;{ }^{2}$ en_kirilyk@ukr.net $;{ }^{3}$ in kirilyk@ukr.net
}

Received 17 October 2018; accepted 15 January 2019; published 30 March 2019

\begin{abstract}
The study establishes the peculiarities and characteristics of how world organic agricultural market develops and functions. The factors of demand and supply of organic agricultural products are singled out. Specific factors influencing the price of organic products, which should take into account the differences in yield and productivity, the need for crop rotation, the risk of harvest loss and loss in storage, and the cost of R\&D are also identified. In modern conditions, prices for organic products are higher than for traditionally produced agricultural products, but the demand for organic products increases, taking into account their impact on human health. The research provides the analysis of market indicators dynamics and levels of organic markets development in comparison with different countries. The influence of institutional systems development that guarantees the quality of organic products in different countries is identified. We discovered the conditions for the development of the organic products market and systematized them into the following groups: organizational and legal, financial and economic, technological and socio-psychological. We identified the prospective directions of the organic products market development, related to the financial mechanisms of investment improvements; strengthening the agricultural producers' rights protection; ensuring food security; improving the system of customers' information; and research conduction. We proved that a systematic approach to the production development on an investment-innovative basis, creation of an institutional environment, sustainable development of rural territories, development and implementation of strategies for the development of vertically integrated structures, taking into account territorial differentiation, is needed for the development of organic agricultural products market.
\end{abstract}

Keywords: organic products; organic agricultural products market; certification; agro-industrial sector; factors of demand and supply; organic market size

Reference to this paper should be made as follows: Proshchalykina, A.; Kyryliuk, E.; Kyryliuk, I. 2019. Prerequisites for the development and prospects of organic agricultural products market, Entrepreneurship and Sustainability Issues 6(3): 1307-1317. http://doi.org/10.9770/jesi.2019.6.3(18)

JEL Classifications: Q13

\section{Introduction}

The organic food market is a global food market dynamic segment, which develops on an innovative basis and has a social and environmental focus. The global organic products market has grown from $\$ 10$ billion in 2010 to 


\section{ENTREPRENEURSHIP AND SUSTAINABILITY ISSUES}

ISSN 2345-0282 (online) http://jssidoi.org/jesi/

2019 Volume 6 Number 3 (March)

http://doi.org/10.9770/jesi.2019.6.3(18)

$\$ 70$ billion in 2016. Expected further growth of this market is $\$ 110$ billion in 2020 (TechSci Research, 2015). Organic production is carried out in 179 countries. The growth of organic food production and sales is caused by the increase of the negative effects of the traditional agriculture intensification with the use of mineral fertilizers, pesticides, oil products, GMO components, and medicines for crop and livestock productivity increase. In contrast to these processes, organic agriculture contributes to environmental safety strengthening, natural resources restoration, biodiversity preservation, and to the energy safety enhance by the use of clean technologies, not only at the national level, but also in the global economy.

In the most of developed countries, the organic agricultural products market is already formed, and has clearly defined economic relations between producers, processors, sellers, controlling bodies, and consumers. Thus, the study and dissemination of this positive experience is relevant.

In economic literature much attention is paid to the study of organic farming and its role in the country growth. Research on the essence and conditions of organic production developments has been done by El-Hage Scialabba \& C.Hattam (2002), T. Kovalenko (2014), V. Grigoryk \& E. Klimov (2016), S. Ivanova \& A. Latyshov (2018) and others. The features of the formation and development of the organic agricultural products market are disclosed in the works of L. Hamzaoui-Essoussi \& M. Zahaf (2009), J. Michelsen, U. Hamm, E. Wynen, E. Roth (1999), E. Sokolova (2012), G. Thompson (2000), L. Zepeda \& J. Li (2007).

Despite the scholars' considerable attention to the peculiarities of the organic agricultural products market development, in our opinion, the scientific substantiation of this market development factors in accordance with national features and foreign experience is insufficient.

The aim of the article is to substantiate scientific regulations and develop the conditions for the organic products market growth at the national level on this basis.

The object of this research is the process of organic agricultural products market formation and development. Methodological basis of this research is a dialectical method of cognition of socio-economic phenomena and processes. The author used general scientific and special methods of research: grouping and classification (to study the essence, functions, and conditions of the organic agricultural products market); analysis and synthesis (to determine the factors of demand and supply for the organic agricultural products market, and the character of their influence); economic-statistical (to determine the dynamics of the market indicators); scientific abstraction (to determine the direction of the organic agricultural products market development).

Author's conclusions and proposals are based on the use of factual data - statistical information, legislative and normative acts of the countries and international organizations studied. Assessments and conclusions can be used to model scenarios for the production and consumption of organic products' development both at the global level and the specific countries and regions.

\section{Terms of development and structure of the organic agricultural market}

Organic production provides the preservation of soils, ecosystems and human health, and is carried out without the harmful resources use (See: El-Hage Scialabba, C.Hattam (ed.), 2002). Organic food production processes include: in crop cultivation - the refusal to use mineral fertilizers, chemical pesticides and GMOs, in animal husbandry - the refusal to use antibiotics, growth stimulators and artificial immunomodulators, as well as the animal keeping methods that restrain their movement. Under such conditions, the cost of organic food production is usually higher than of the traditional one. To reduce the dependence of organic production on natural causes it is necessary to use scientifically grounded methods of agriculture. In crop cultivation this includes choosing the appropriate species and varieties which can resist pests and diseases; the use of crop rotation, mechanical, 


\section{ENTREPRENEURSHIP AND SUSTAINABILITY ISSUES}

ISSN 2345-0282 (online) http://jssidoi.org/jesi/

2019 Volume 6 Number 3 (March)

http://doi.org/10.9770/jesi.2019.6.3(18)

physical and biological methods of protection; the use of microbiological, vegetable and animal origin minerals as biodegradable fertilizers which do not lead to degradation of soils. In animal husbandry, the animals are kept based on their physiological and behavioural needs, they are provided with living conditions which adequately take into account the main aspects of their natural behaviour; the animals should be fed with the organically produced feedstuffs and natural substances of non-agricultural origin; mainly natural methods of reproduction are used; the disinfection of premises should be done by authorized means only.

Organic agricultural products market is a combination of relationships between buyers and sellers based on selling and purchasing of organic agricultural products.

This market includes following segments:

1. The market for organic products (raw materials) of vegetable origin includes of crop production sale/purchase, the cultivation and use of plants as a forage base for organic livestock breeding.

2. The market for organic products (raw materials) of animal origin includes the sale/purchase of livestock breeding products and their use for organic food production.

3. The market for organic aquaculture products includes the sale/purchase of fish, crustaceans and shellfish.

4. The market for organic beekeeping products (raw materials) includes bees' breeding and receiving honey, wax and other bee products.

5. Wildlife market includes food and medicinal plants and mushrooms growing in ecologically clean areas and collected by man for consumption and sale (See: Kovalenko T., 2014).

The organic agricultural market is a niche market (only a certain proportion of consumers are ready to pay extra for the quality of products). Also, this market is cross-sectored, as it covers various segments of the food and non-food markets.

The organic food market development demands that the following prerequisites are presented, as shown in Table 1.

Table 1. Conditions for the organic products market development

\begin{tabular}{|c|c|c|}
\hline $\begin{array}{l}\text { Group of } \\
\text { Influence } \\
\text { Factors } \\
\end{array}$ & Aspects & Implementation Instruments \\
\hline \multirow[t]{8}{*}{$\begin{array}{l}\text { Organizational } \\
\text { and Legal }\end{array}$} & $\begin{array}{l}\text { Development of the legal field for the } \\
\text { production and sale of organic products. }\end{array}$ & $\begin{array}{l}\text { Formation of the legal framework to regulate the properties, cultivation } \\
\text { conditions, and sale of organic agricultural products. }\end{array}$ \\
\hline & Planning and programming. & $\begin{array}{l}\text { Creation of state strategies and programs for organic production } \\
\text { development. }\end{array}$ \\
\hline & $\begin{array}{l}\text { Countries organic product's certification } \\
\text { and marking system development. }\end{array}$ & $\begin{array}{l}\text { International standards implementation and development of national } \\
\text { standards for organic agricultural production. }\end{array}$ \\
\hline & $\begin{array}{l}\text { Innovations' stimulation } \\
\text { commercialization. }\end{array}$ & $\begin{array}{l}\text { Stimulation of R\&D aimed to create biological means of plant and animal } \\
\text { protection; brining out new regionalized varieties of plants resistant to } \\
\text { pests, diseases and bad weather conditions; organic fertilizers production; } \\
\text { implementation of innovative technologies for the processing, storage and } \\
\text { transportation of organic products. }\end{array}$ \\
\hline & $\begin{array}{l}\text { Information and consulting support for } \\
\text { existing innovative solutions; sharing the } \\
\text { practical experience in production and } \\
\text { processing of organic products. }\end{array}$ & $\begin{array}{l}\text { Create on-line information base, which highlights the peculiarities of this } \\
\text { way of production, legal acts and infrastructure elements. } \\
\text { Consulting centres and demo farms creation, producers' associations } \\
\text { support. }\end{array}$ \\
\hline & \multirow[t]{3}{*}{ Infrastructure development. } & Support and improvement of sales channels. \\
\hline & & Development of the institutions for organic products certification. \\
\hline & & Creation of the organic raw materials processing infrastructure. \\
\hline $\begin{array}{l}\text { Financial and } \\
\text { Economic }\end{array}$ & $\begin{array}{l}\text { Direct state support of organic producers. } \\
\text { It meets the requirements of the WTO's } \\
\text { "green basket", which increases the state } \\
\text { regulation opportunities. }\end{array}$ & $\begin{array}{l}\text { 1. Support of the farmers to improve the products quality and reduce } \\
\text { mineral fertilizers use. } \\
\text { 2. Subsidies to organic producers or compensatory payments to producers } \\
\text { who made transition to organic production. } \\
\text { 3. Total or partial repayment of certification value. }\end{array}$ \\
\hline
\end{tabular}


ENTREPRENEURSHIP AND SUSTAINABILITY ISSUES

ISSN 2345-0282 (online) http://jssidoi.org/jesi/

2019 Volume 6 Number 3 (March)

http://doi.org/10.9770/jesi.2019.6.3(18)

\begin{tabular}{|l|l|l|}
\hline & $\begin{array}{l}\text { Creation of an extensive financial support } \\
\text { system for producers. }\end{array}$ & Preferential taxation and loan, venture capital investments, insurance. \\
\hline Technological & $\begin{array}{l}\text { Ecologically clean lands and areas } \\
\text { existence. }\end{array}$ & $\begin{array}{l}\text { State programs to protect lands and soil fertility restoration. } \\
\text { Strengthening the land use and environment protection control. }\end{array}$ \\
\cline { 2 - 3 } & $\begin{array}{l}\text { Organic production technologies } \\
\text { development. }\end{array}$ & $\begin{array}{l}\text { State investments to the building, reconstruction and renovation of } \\
\text { irrigation objects. }\end{array}$ \\
\cline { 2 - 4 } $\begin{array}{l}\text { Crop cultivation and animal husbandry } \\
\text { technologies development. }\end{array}$ & $\begin{array}{l}\text { Support of the commercialization of the researches done by scientific } \\
\text { institutions, creating motivational factors for individuals. }\end{array}$ \\
\hline $\begin{array}{l}\text { Socio- } \\
\text { psychological }\end{array}$ & $\begin{array}{l}\text { Formation of the strategic marketing } \\
\text { measures to create the demand. }\end{array}$ & $\begin{array}{l}\text { Producer specifies ecological characteristics of the product during its } \\
\text { positioning. Customer's perception of consumer value of organic product } \\
\text { is not only the result of producer's efforts but of consumer culture and } \\
\text { ecological conciseness as well. Long-term effect of organic products } \\
\text { consumption-medication expenses decree and longer life. }\end{array}$ \\
\cline { 2 - 3 } & Low level of ecological consciousness & \begin{tabular}{l} 
Informational support both of producers and consumers \\
\hline
\end{tabular}
\end{tabular}

Source: Composed by the author based on sources (Kovalenko T., 2014; Hamzaoui-Essoussi L. and Zahaf M., 2009; El-Hage

Scialabba, C.Hattam (ed.), 2002)

Only with an integrated combination of organizational, legal, financial, technological, and socio-psychological preconditions it is possible to achieve systematic development of organic agriculture in the country.

\section{Features of the organic agricultural products market development}

The analysis of production and marketing of organic products researches and practices in different countries allowed identifying the following features and characteristics of the organic agricultural products market development and functioning (Table 2).

Table 2. Features of the organic agricultural products market development and functioning

\begin{tabular}{|c|c|}
\hline Market Feature & Feature's Content \\
\hline $\begin{array}{l}\text { Demand and its } \\
\text { factors }\end{array}$ & $\begin{array}{l}\text { Demand is elastic because of the higher prices (30-50\%) in comparison with the ones of conventional food and } \\
\text { substitutes availability. } \\
\text { Demand factors: } \\
\quad \text { - buyers' high income; } \\
\text { - } \quad \text { popularization of healthy lifestyle and ecological consciousness; } \\
\text { - difference in prices with the substitute products (products of traditional agriculture); } \\
\text { - } \quad \text { availability of organic products and marketing efforts to stimulate the sale of these products. }\end{array}$ \\
\hline Target audience & $\begin{array}{l}\text { The consumers with middle and high income level, people who have a healthy lifestyle, food and non-food organic } \\
\text { products producers. }\end{array}$ \\
\hline $\begin{array}{l}\text { Supply and its' } \\
\text { factors }\end{array}$ & $\begin{array}{l}\text { The proposal is elastic which is caused by the possibility of producer's return to traditional agricultural products. } \\
\text { Supply factors: } \\
\text { - limited production factors - land's appropriate quality, planting materials, plant protection products and } \\
\text { - weed control, means of labour; } \\
\text { peculiarity of the production process - low capital turnover, producers' territorial dispersion and } \\
\text { - } \quad \text { infrastructure development; } \\
\text { - } \quad \text { availability of investments and the level of their accessibility; } \\
\text { - } \quad \text { availability and access to technologies; } \\
\text { - } \quad \text { direct and indirect state support; } \\
\text { - } \text { manufacturer opportunities to expand the market through the entry into foreign markets. }\end{array}$ \\
\hline $\begin{array}{l}\text { Products character } \\
\text { and the features of } \\
\text { conjuncture }\end{array}$ & $\begin{array}{l}\text { Organic products have additional consumer properties - no harmful impurities, higher concentrations of useful } \\
\text { amino acids, vitamins, and nutrients. Organic farming performs special functions that are not typical for the } \\
\text { traditional agriculture: environmental and social functions. Supply is limited due to the relatively small production } \\
\text { volumes and limited distances to which fresh product can be delivered. These organic products do not occupy a big } \\
\text { niche in any country; they rather form their own specific market. In developed countries, demand exceeds the } \\
\text { supply, so it is satisfied by import. }\end{array}$ \\
\hline Competition & Monopolistic competition - there is an opportunity to segment the customers, product substitutes are presented, \\
\hline
\end{tabular}




\begin{tabular}{|c|c|}
\hline & high prices, non-pricing competition is important. \\
\hline Pricing peculiarities & $\begin{array}{l}\text { The reason for organic products high prices is their high cost, which is caused by the high labour intensity per } \\
\text { production unit and the production modernization. Only a substantial increase of demand can lead to the economies } \\
\text { of scale. Certification costs are an important component of the value. A significant part of the value added in the } \\
\text { structure of the retail price is formed when the product is stored, processed, transported and traded. The price } \\
\text { includes the projected risk of the crop loss. }\end{array}$ \\
\hline Sales channels & $\begin{array}{l}\text { 1. } \quad \text { Sales of certified processing enterprises. } \\
\text { 2. } \quad \text { Sales through sales cooperatives. } \\
\text { 3. } \quad \text { Direct sales (own stores, online stores, catering institutions, farm markets). } \\
\text { 4. } \quad \text { Sales to trade institutions (supermarkets and specialized stores). }\end{array}$ \\
\hline Risks & $\begin{array}{l}\text { 1. Inflation processes in the country. In a context of population' purchasing power decrease, cheap products } \\
\text { become popular, rather than useful. } \\
\text { 2. Increased costs. } \\
\text { 3. Reduction of suitable farmlands or deterioration of the ecological situation in the region. } \\
\text { 4. State policy changes, reduction of state support. } \\
\text { 5. Bad weather conditions. } \\
\text { 6. Partial crop losses during the transition period due to decreased production volumes in comparison with } \\
\text { 7. The possibility of product counterfeiting and quality decline by unscrupulous competitors }\end{array}$ \\
\hline
\end{tabular}

Source: Composed by the author based on sources (Sokolova G., 2012; Michelsen J., Hamm U., Wynen E. and Roth E., 1999; Thompson G., 2000; Zepeda L. \& Li J.,2007; Sardak, S., Korneyev, M., Simakhova, A. \& Bilskaya, O. (2017)

The global market for organic agricultural products is a dynamic segment of the global market. Organic products are produced on 50.9 million hectares (1.1\% of all farmlands in the world). Indicators describing the production and consumption of organic agricultural products in the world are shown in Table 3.

Table 3. The main indicators of the development of the organic agricultural products market in the world

\begin{tabular}{|l|l|l|l|l|l|l|l|l|l|l|l|l|}
\hline Indicator & 2005 & 2006 & 2007 & 2008 & 2009 & 2010 & 2011 & 2012 & 2013 & 2014 & 2015 & 2016 \\
\hline $\begin{array}{l}\text { Number of countries with data on organic } \\
\text { agriculture }\end{array}$ & 122 & 135 & 140 & 155 & 161 & 161 & 162 & 164 & 170 & 172 & 179 & 178 \\
\hline $\begin{array}{l}\text { Number of organic producers, million } \\
\text { producers }\end{array}$ & 0,7 & 0,9 & 1,2 & 1,4 & 1,8 & 1,6 & 1,8 & 1,9 & 2 & 2,2 & 2,4 & 2,7 \\
\hline Organic agricultural land, million hectares & 28,3 & 30,2 & 31,5 & 34,5 & 36,3 & 35,7 & 37,5 & 37,6 & 43,2 & 44,4 & 50,9 & 57,8 \\
\hline Share of total agricultural land, \% & 0,6 & 0,6 & 0,7 & 0,7 & 0,8 & 0,8 & 0,8 & 0,8 & 0,9 & 0,9 & 1,1 & 1,2 \\
\hline Organic market size, billion US dollars & 33,2 & 40,2 & 46,1 & 50,2 & 54,9 & 59,1 & 62,8 & 64 & 72 & 80 & 81,6 & 89,7 \\
\hline
\end{tabular}

Sources: The World of Organic Agriculture. Retrieved from: http://www.organic-world.net/yearbook.html

FiBL data on organic agriculture worldwide. Retrieved from: https://statistics.fibl.org/world/key-indicators-world.html

The given proves the constant growth of organic agricultural products market. Both the number of countries that produce organic food and the number of producers are growing. The amount of farmland used for organic production has increased 2 times. Compared to 2005 the market capacity has increased 2,7 times. The most of organic products are sold in developed countries. However, these regions are not self-sufficient, since production does not meet the demand. To balance the underproduction, these products are imported.

As of 2016, there were 2,7 million certified organic food producers in the world. Their distribution by regions is shown in Fig. 1. The largest number of producers in 2016 was in India (835000), Uganda (210352), and Mexico (210000). 


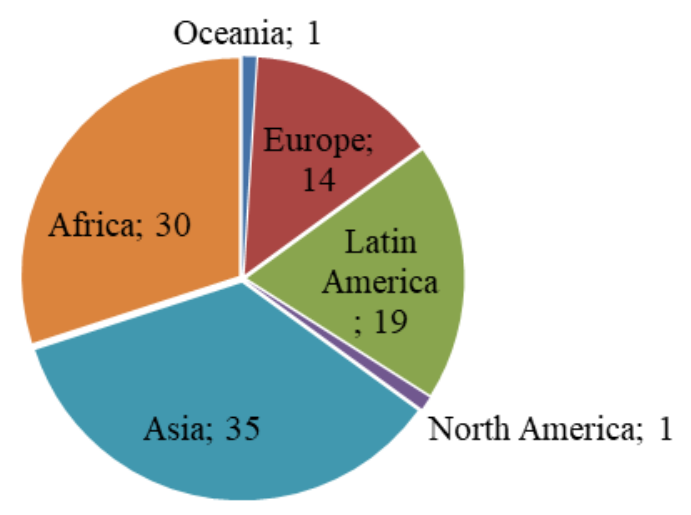

Fig. 1. Distribution of organic producers by region in $2015, \%$

Source: FiBL data on organic agriculture worldwide. Retrieved from: http://www.organic-world.net/statistics/statistics-data-tables/owstatistics-data-key-data.html?tx_statisticdata_pi1\%5Bcontroller\%5D=Element2Item\&cHash=1454ae80c62646f2ea29bd52b7a5248d

The structure of the organic farmlands is shown in Figure 2.

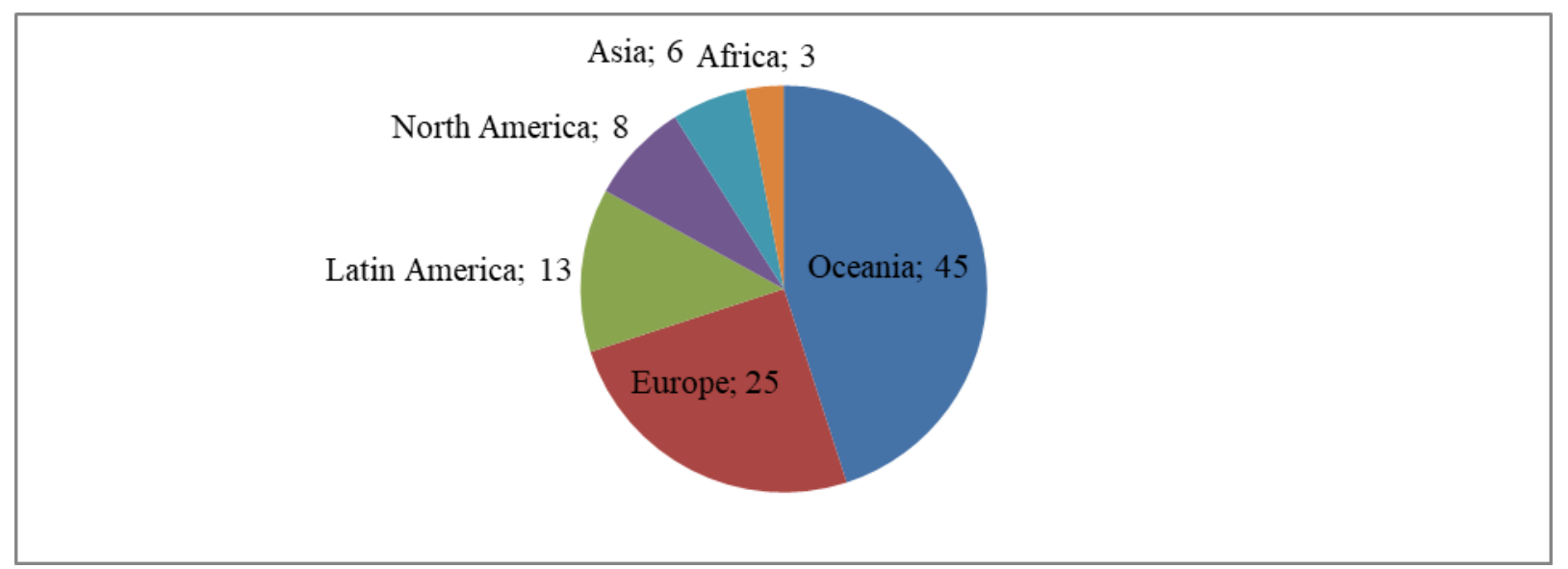

Fig. 2. Distribution of organic agricultural land by region in $2015, \%$

Source: FiBL data on organic agriculture worldwide. Retrieved from: http://www.organic-world.net/statistics/statistics-data-tables/owstatistics-data-key-data.html?tx statisticdata pi1\%5Bcontroller\%5D=Element2Item\&cHash=1454ae80c62646f2ea29bd52b7a5248d

The data shows that organic food production is massive in highly developed countries, and small producers predominate in developing countries. The first three countries with the largest areas of organic farmlands are Australia, Argentina, and the USA. The average size of one farm in these countries is 10046 hectares, 3078 hectares and 169 hectares respectively.

In general, the top ten countries with the largest organic farmland areas possess 31,8 million hectares, which is $73 \%$ of all organic farmlands in the world (See: The World of Organic Agriculture Yearbook, 2017).

Countries with major organic products markets include the United States $(\$ 43,1$ billion in 2016), Germany $(\$ 10,5$ billion in 2016), France ( $\$ 7,5$ billion in 2016).

The volume of organic agricultural products sales by regions is reflected in Table 4 . 


\section{ENTREPRENEURSHIP AND SUSTAINABILITY ISSUES}

ISSN 2345-0282 (online) http://jssidoi.org/jesi/

2019 Volume 6 Number 3 (March)

http://doi.org/10.9770/jesi.2019.6.3(18)

Table 4. Retail sales by regions, Mio $€$

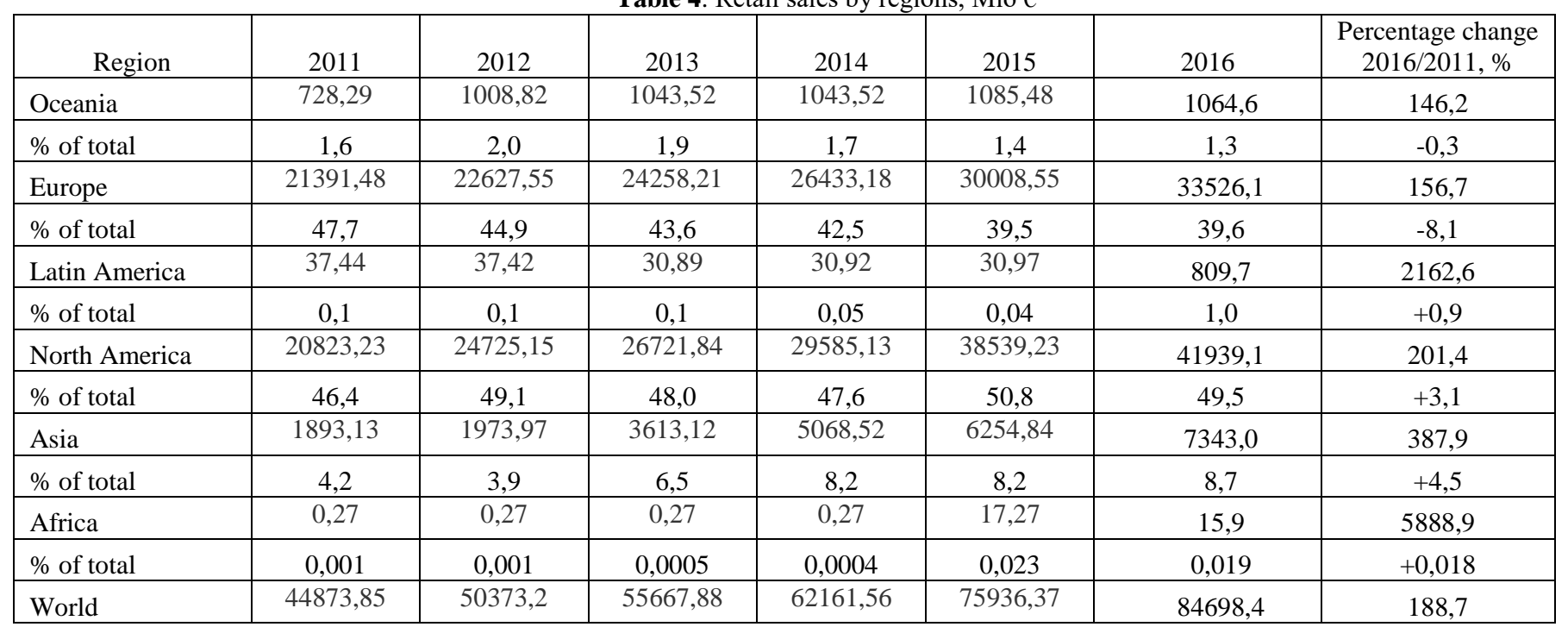

Sources: FiBL data on organic agriculture worldwide. Retrieved from: https://statistics.fibl.org/world/retail-salesworld.html?tx_statisticdata_pi1\%5Bcontroller\%5D=Element2Item\&cHash=35a0fcd89ae099d2ff14fe1ddb38a1aa

Growth in sales is observed in all regions except Europe and Oceania. Sales in Africa have changed most dynamically- increased 6 times. This is so due to the fact that African countries are trying to enter the world organic product markets to generate profit, since they have competitive advantages because of low industrial waste contamination. Most of the sales go to the countries in North America and Europe (mostly EU countries). They accounted for more than $90 \%$ of sales in 2016.

The dynamics of organic products consumption in the world (per capita) is shown in Figure 3.

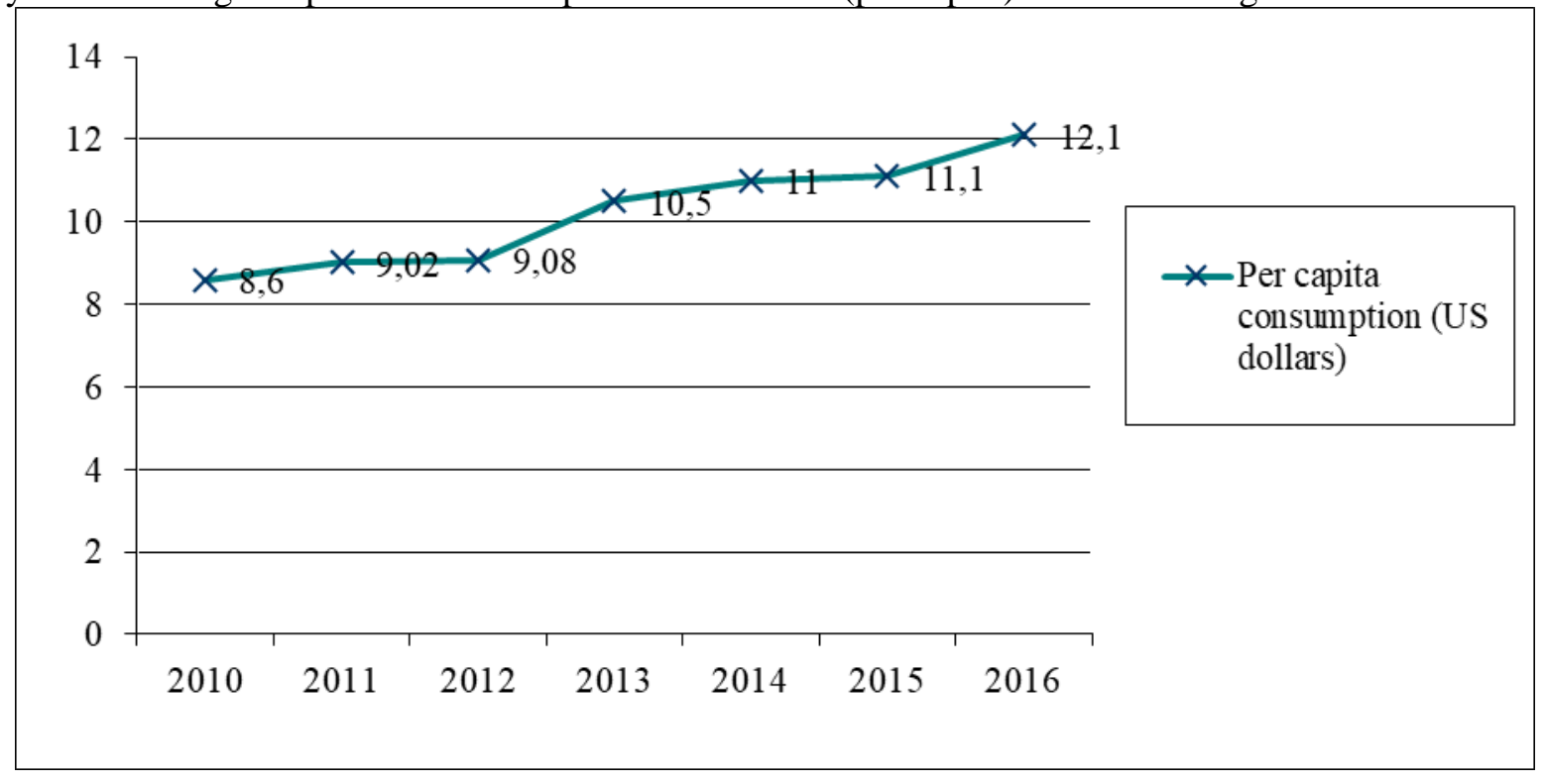

Figure 3. Per capita consumption of agrarian organic products (US dollars)

Source: FiBL data on organic agriculture worldwide. Retrieved from: http://www.organic-world.net/statistics/statistics-data-tables/ow$\underline{\text { statistics-data-key-data.html?tx_statisticdata_pi1\%5Bcontroller\%5D=Element2Item\&cHash=1454ae80c62646f2ea29bd52b7a5248d }}$ 
The high level of organic products consumption per capital in recent years is typical for Switzerland (\$304 in 2016), Denmark (\$252 in 2016), and Sweden (\$218 in 2016) (Figure 4).

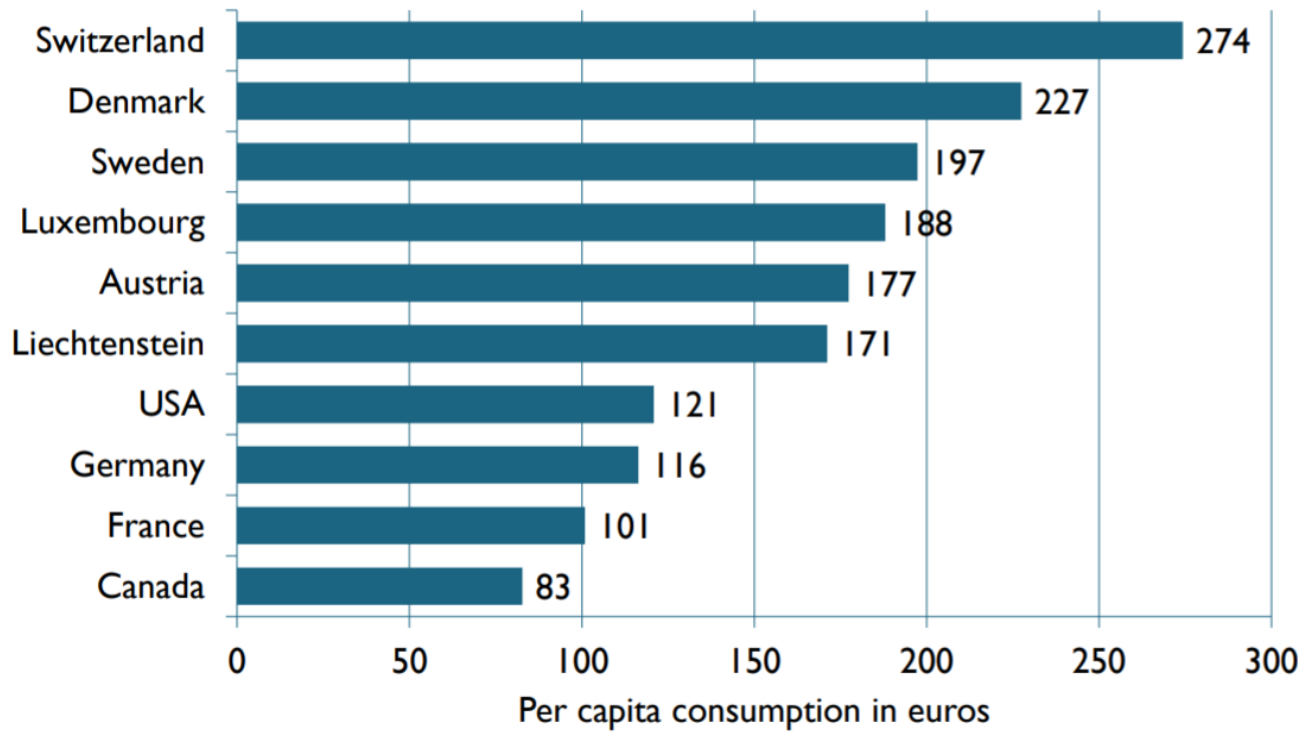

Figure 4. The 10 countries with highest per capita organic agrarian products consumption, $€$

Source: The World of Organic Agriculture. Retrieved from: https://shop.fibl.org/CHen/mwdownloads/download/link/id/1093/?ref=1

The list of these countries has remained virtually unchanged over the past five years, indicating steady high consumption of organic products in these countries. They have established markets for organic products that tend to grow. To analyze supply-demand situation it is important to analyze the structure and the dynamics of exportimport operations by regions. The relevant statistics is shown in Tables 5 and 6.

Table 5. Regional structure of organic agricultural products export, Mio $€$

\begin{tabular}{|c|c|c|c|c|c|}
\hline Region & 2011 & 2012 & 2013 & 2014 & 2015 \\
\hline Oceania & 246,89 & 237,14 & 383,34 & 383,34 & 398,82 \\
\hline$\%$ of total & 4,9 & 3,8 & 5,2 & 3,7 & 3,5 \\
\hline$\%$ of total & 52,4 & 49,9 & 51,4 & 41,0 & 40,5 \\
\hline Latin America & 994,01 & 1306,53 & 1283,83 & 1401,43 & 1229,36 \\
\hline North America & 581,53 & 705,25 & 774,78 & 3202,83 & 2828,73 \\
\hline$\%$ of total & 11,5 & 11,3 & 10,5 & 31,1 & 25,1 \\
\hline Asia & 480,2 & 780,49 & 902,88 & 853,57 & 1848,47 \\
\hline$\%$ of total & 9,5 & 12,5 & 12,3 & 8,3 & 16,4 \\
\hline
\end{tabular}

Source: FiBL data on organic agriculture worldwide. Retrieved from: http://www.organic-world.net/statistics/statistics-data-tables/owstatistics-data-key-data.html?tx statisticdata pi1\%5Bcontroller\%5D=Element2Item\&cHash=1454ae80c62646f2ea29bd52b7a5248d 
Export volumes of organic agricultural products increased in all regions (the total increase for the analyzed period is 223\%). North America has shown the highest growth (4.8 times in 2011-2015). The largest share in the structure of export belongs to Europe (40.5\% in 2015), although its share declined during the analyzed period. The role of Asian and African countries in the export of organic agricultural products is increasing.

Table 6. Regional structure of import of organic agricultural products, Mio $€$

\begin{tabular}{|c|c|c|c|c|c|}
\hline Region & 2011 & 2012 & 2013 & 2014 & 2015 \\
\hline Oceania & - & 177,31 & 107,08 & 107,08 & 107,08 \\
\hline$\%$ of total & - & 9,5 & 4,2 & 3,0 & 3,3 \\
\hline Europe & 620,77 & 1249,4 & 1332,8 & 1517,2 & 1648,58 \\
\hline$\%$ of total & 56,3 & 67,1 & 52,7 & 42,0 & 51,1 \\
\hline Latin America & 1,19 & 1,19 & 6,31 & 8,27 & 8,29 \\
\hline$\%$ of total & 0,1 & 0,1 & 0,2 & 0,2 & 0,3 \\
\hline North America & 479,7 & 386,22 & 1036,53 & 1942,59 & 1436,68 \\
\hline$\%$ of total & 43,5 & 20,8 & 41,0 & 53,7 & 44,6 \\
\hline Asia & - & 46,58 & 46,58 & 40,7 & 22,95 \\
\hline$\%$ of total & - & 2,5 & 1,8 & 1,1 & 0,7 \\
\hline Africa & 0 & 0 & 0 & 0 & 0 \\
\hline$\%$ of total & 0,00 & 0,00 & 0,00 & 0,00 & 0,00 \\
\hline World & 1101,67 & 1860,71 & 2529,3 & 3615,85 & 3223,57 \\
\hline
\end{tabular}

"_" not available

Source: The World of Organic Agriculture. Retrieved from: http://www.organic-world.net/yearbook.html

The volume of organic products import increased 2.9 times during the analyzed period. The highest growth occurred in the countries of South America. In the structure of import the largest share belongs to European countries $(51,1 \%$ in 2015$)$ and North America (44,6\%). Asia was the only region where the decline in import was observed.

The given data shows the growth of international trade role in the organic products market and the consolidation of new entrants - the countries of Asia and Africa.

\section{Problematic aspects of the development of the world market of organic agricultural products}

Several peculiarities and problematic aspects can be identified in the development of the global organic agricultural products market:

1. Own production capacity of the main consumer countries of organic products is practically exhausted, and consumption is increasing annually. In order to meet the growing needs of the population, it is necessary to expand the cooperation between developed countries and the countries with underdeveloped markets for organic products but insufficient resources for their development. These are the countries of Central Asia, Latin America, Africa, and Eastern Europe. However, this cooperation should not only involve the capacity growth, but the environmental safety strengthening also.

2. Due to the fact that the regions of organic production and consumption do not match, logistic networks should be established, and the investments in the processing of organic raw materials into goods with high value added need to be done. 


\section{ENTREPRENEURSHIP AND SUSTAINABILITY ISSUES}

ISSN 2345-0282 (online) http://jssidoi.org/jesi/

2019 Volume 6 Number 3 (March)

http://doi.org/10.9770/jesi.2019.6.3(18)

3. To overcome the asymmetry of information on the organic products market, there is a need in further development of the standardization and unification systems of the quality control, including the international level.

4. The level of commodity diversification is growing, although not because of the new products, but due to the increasing the variety of types of certified goods.

5. Under the pressure of technical progress, increasing demands in the quality and safety of products, the role of vertical and horizontal integration is growing. Large farms became more competitive. Remaining alternative to small and medium-sized enterprises is a separate niche of markets for organic products.

\section{Conclusions}

World organic production has a significant potential for becoming the basis for the sustainable development of any country and the world economy as a whole. The development of the organic agricultural market contributes to the increase of the ecological and economic efficiency of the country economy. The organic products market, as well as the agricultural market in general, is characterized by specific factors of demand and supply. Factors of growing demand are: the growth of living standards and willingness to pay for product's high quality and environmental safety; increasing consumer awareness of the health benefits of organic food; the availability of organic products and marketing efforts to stimulate the sales of these products. The supply is positively affected by the following factors: product innovations and economies of scale that gradually leads to the production cost decrease and the price approximation to the conventional food products; state programs to support the producers of organic products; the availability of infrastructure; and better opportunities for producers to enter the external markets.

Research shows that the organic products market has reached the highest levels in those countries where production, consumption and quality control systems have been developed in a balanced way. The most successful experience is one of the North European countries - Denmark, Sweden, France, Switzerland, and Germany. The high level of consumers' income has also contributed to the development of this market in the US, Canada, China, and Australia.

Prospects for the development of the organic products market in the country are closely linked to the formation and development of such factor groups: organizational and legal, financial and economic, technological and sociopsychological. Such a systematization of factors makes it possible to improve and develop effective measures for the implementation of a system for organic agricultural production taking into account the influence of these factors.

\section{References}

Global Organic Food Market Forecast and Opportunities 2020. 2015. Retrieved from https://www.techsciresearch.com/report/globalorganic-food-market-forecast-and-opportunities-2020/450.html

FiBL data on organic agriculture worldwide. 2018. Retrieved from http://www.organic-world.net/statistics/statistics-data-tables/owstatistics-data-key-data.html?tx statisticdata pi1\%5Bcontroller\%5D=Element2Item\&cHash=1454ae80c62646f2ea29bd52b7a5248d

Gavaza, E. 2013. Derzhavna pidtrymka rozvytku rynku orhanichnoi produktsii [State support of organic products market development], Visnyk Zhytomyrskoho natsionalnoho ahroekolohichnoho universytetu, 1-2(2): $332-340 . \quad$ Retrieved from http://nbuv.gov.ua/UJRN/Vzhnau_2013_1-2(2)__43 (in Ukr.)

Grigoryk, V. \& Klimov, E. 2016. Development of organic agriculture in the world and Kazakhstan. FAO. (in Russ).

Ivanova, S.; Latyshov, A. 2018. Sustainable entrepreneurship: agrarian policy in South Korea. Entrepreneurship and Sustainability Issues, 5(4), 748-760. https://doi.org/10.9770/jesi.2018.5.4(4) 


\section{ENTREPRENEURSHIP AND SUSTAINABILITY ISSUES}

ISSN 2345-0282 (online) http://jssidoi.org/jesi/

2019 Volume 6 Number 3 (March)

http://doi.org/10.9770/jesi.2019.6.3(18)

Kovalenko, T. 2014. Vyrobnytstvo orhanichnoi silhospproduktsii ta syrovyny [Production of organic agricultural products and raw materials]. Ahrosvit sohodni №5. Retrieved from http://www.agro-business.com.ua/u-pravovomu-poli/2107-vyrobnytstvo-organichnoiisilgospproduktsiii-ta-syrovyny.html (in Ukr.)

Hamzaoui-Essoussi, Leila and Zahaf, Mehdi. 2009. The Organic Food Market: Opportunities and Challenges. Retrieved from http://cdn.intechopen.com/pdfs/25733.pdf

El-Hage Scialabba, C.Hattam (ed.). 2002. Organic agriculture, environment and food security. - Rome: FAO.

Sokolova, G. 2012. Teoryia y praktyka razvytyia myrovoho runka produktsyy orhanycheskoho selskoho khoziaistva [Theory and practice of development of the world organic products market]. Moskow: Izdatelstvo IP Nasyrdinova V.V. (in Russ).

Michelsen, J; \& Hamm, U.;\& Els Wynen, E.; \& Roth, E. 1999. The European market for organic products: growth and development. Retrieved from https://www.uni-hohenheim.de/i410a/ofeurope/organicfarmingineurope-vol7.pdf

Sardak, S., Korneyev, M., Simakhova, A. \& Bilskaya, O. (2017). Global factors which influence the directions of social development. Problems and Perspectives in Management, 15(3), 323-333. http://10.21511/ppm.15(3-2).2017.02

The World of Organic Agriculture. Retrieved from http://www.organic-world.net/yearbook.html

Thompson, Gary. 2000. International Consumer Demand for Organic Foods. Retrieved from http://horttech.ashspublications.org/content/10/4/663.full.pdf

Zepeda, L., \& Li, J. 2007. Characteristics of Organic Food Shoppers, Journal of Agriculture and Applied Economics, $39(1)$, 17-28. https://doi.org/10.1017/S1074070800022720

Short biographical note about the contributors at the end of the article (name, surname, academic title and scientific degree, duties, research interests):

Alina Proshchalykina is the Associate Professor of Economics and International Economic Relations Department Bogdan Khmelnytsky National University of Cherkasy. Ph.D. in Economics. Head of the scientific project "Innovative Factors of Sustainable Food Supply and Development of Bioeconomics in Ukraine". Research interests: bioteconomy, organic production, biotechnology, economic growth, innovation.

ORCID ID: https://orcid.org/0000-0002-9867-2555

Yevhenii Kyryliuk is the Professor of Economics and International Economic Relations Department Bogdan Khmelnytsky National University of Cherkasy. Doctor in Economics. Current Coordinator of the scientific project "Innovative Factors of Sustainable Food Supply and Development of Bioeconomics in Ukraine". Research interests: the agrarian market, problems of food security, state regulation, pricing and infrastructure support for the development of the economy.

ORCID ID: https://orcid.org/0000-0001-7097-444X

Iryna Kyryliuk is the lecturer at the Department of Management and Economic Security Bogdan Khmelnytsky National University of Cherkasy. Research interests: management of quality and product safety, management of certification processes and standardization in the conditions of creating a free trade zone with the EU, problems of food security, state regulation, pricing and infrastructure provision of economic development.

ORCID ID: https://orcid.org/0000-0003-3365-7239

Copyright (C) 2019 by author(s) and VsI Entrepreneurship and Sustainability Center

This work is licensed under the Creative Commons Attribution International License (CC BY).

http://creativecommons.org/licenses/by/4.0/

(c) (i) Open Access 